Original research / Orijinal araştırma

\title{
Status of hepatitis C virus infection in lung cancer patients
}

\author{
Akciğer kanserli hastalarda hepatit $\mathrm{C}$ virüs enfeksiyonun yeri \\ Sulhattin Arslan ${ }^{1}$, Neslihan Taş, ibrahim Akkurt \\ Department of Chest Diseases, Cumhuriyet University of School of Medicine, 58140 \\ Sivas
}

\begin{abstract}
Aim. The aim of this study was to evaluate the association between HCV and lung cancer. Methods. The study included 60 patients who admitted department of chest diseases our hospital for diagnosis of lung cancer. These patients were performed the blood test for HCV before to invasive procedures. Results: Of 60 patients included in this study, 58 (96.7\%) were male and $2(3.3 \%)$ were female. There was a statistically no significant difference between patients with Anti-HCV (+) and Anti-HCV (-) for gender and age $(p>0.05)$. We found that anti-HCV antibodies were positive in 3 of 60 (5\%) patients with lung cancer. Histologic types of lung cancer were $38.0 \%$ squamous cell cancer, $30.0 \%$ adenocarcinoma, $10.0 \%$ undifferentiated, and $21.7 \%$ small cell lung cancer. There was a statistically non-significant difference between patients with antiHCV (+) and anti-HCV (-) for histological type of lung cancer $(p>0.05)$. Conclusions: The development of lung cancer is a multifactorial process, including the environment factors, smoking, certain occupations, and genetic factors. HCV positivity alone may not be sufficient evidence for cause lung cancer. Therefore, there is a need studies that have large numbers of patients with HCV infection and lung cancer patients for this association.
\end{abstract}

Keywords: Lung cancer, hepatitis C virus

\section{Özet}

Amaç: Bu çalışmanın amacı akciğer kanseri ile Hepatit C virüsü arasındaki ilişkiyi incelemektir. Yöntem: Hastanemiz göğüs hastalıkları bölümüne akciğer kanseri ön

\footnotetext{
${ }^{1}$ Corresponding author:

Dr. Sulhattin Arslan, Göğüs Hastalıkları Anabilim Dalı, Cumhuriyet Üniversitesi Tıp

Fakültesi, TR-58140 Sivas

Email: sulhattinaslan@mynet.com
} 
tanısıyla başvuran 60 hasta çalışmaya alındı. Hastalara tanısal invaziv girişimler yapmadan önce hepatit $\mathrm{C}$ için kan örnekleri alındı. Bulgular: Çalışmaya dahil edilen 60 hastanın 58'i (\%96.7) erkek, 2'si (\%3.3) kadındı. Altmış hastanın 3'ü (\%5) anti HCV (+) idi. Anti-HCV (+) ve anti-HCV (-) gruplar arasında yaş ve cinsiyet bakımından anlamlı bir fark yoktu ( $p>0.05$ ). Akciğer kanserli hastaların histolojik tipi olarak \%38.0'ı squamöz hücreli kanser, \% 30.0'ı adenokarsinoma, \%10.0'ı tiplendirilemeyen ve \% 21.7'si küçük hücreli akciğer kanseri idi. Anti-HCV (+) ve anti-HCV (-) gruplar arasında akciğer kanserinin histolojik tipi bakımından anlamlı bir fark yoktu ( $p>0.05)$. Sonuçlar: HCV pozitifliği akciğer kanserinin nedeni olarak göstermek için yeterli kanıt olmayabilir. Akciğer kanserinin gelişmesinde sigara, bazı meslekler, çevresel ve genetik faktörleri içeren multifaktöryel etkenler rol oynamaktadır. Akciğer kanseri ile HCV infeksiyonu arasındaki ilişki değerlendirmek için ileride daha geniş serili çalışmalara ihtiyaç vardır.

Anahtar sözcükler: Akciğer kanseri, hepatit C virüsü

\section{Introduction}

Hepatitis $\mathrm{C}$ virus (HCV) infection is an increasingly recognized as a major healthcare problem, affecting more than 170 million individuals worldwide (1-3). Although the majority of infected persons have few or no clinical symptoms, individuals with chronic $\mathrm{HCV}$ infection have an increased risk of developing cirrhosis, hepatocellular carcinoma, non-Hodgkin's lymphoma, pulmonary fibrosis, and oral carcinoma (4-9).

Lung cancer is one of the most important diseases in respiratory medicine with an increase in smoking addiction (10). Worldwide, lung cancer is responsible for $12.8 \%$ of cancer cases and $17.8 \%$ of cancer deaths (11). It only caused death of more than one million people in $2001(10,12)$.

Some specific viruses has been reported as having a role in $15 \%$ of human cancer cases (13). Viruses associated with human cancer have a role in oncogenesis. HCV has been shown to be associated in the pathogenesis of various cancers, including hepatocellular carcinoma, non-Hodgkin's lymphoma, oral cancer, malignant lymphoma, thyroid cancer $(5,6,14)$. But the association of lung cancer and HCV infection is not well known.

The aim of this study was to evaluate the association between HCV and lung cancer.

\section{Material and Methods}

The study included 60 patients who admitted department of chest diseases our hospital for diagnosis of lung cancer. These patients were performed the blood test for HCV before to invasive procedures. A routine evaluation including a detailed medical history, physical examination, chest radiography, thorax $\mathrm{CT}$, blood count and biochemistry was performed in all patients. Age, gender were recorded. Primary lung carcinoma was histologically subclassified. The cases were questioned stories for the blood transfusion, injection drug users, hepatitis, and the operation. 
Serum samples for anti-HCV antibodies were detected by the 2nd generation Enzyme Linked Immunosorbent Assay (ELISA). The Chi-square tests were used for the statistical analyses. $P$ value of less than 0.05 was accepted as significant.

\section{Results}

Of 60 patients included in this study, $58(96.7 \%)$ were male and $2(3.3 \%)$ were female. There was a statistically non-significant difference between patients with Anti-HCV (+) and Anti-HCV (-) for gender ( $p>0.05$ ). Mean age of study population was $59 \pm 5.0$ with a range of 24-77. Mean age of Anti-HCV (+) population was $58 \pm 8.2$ and mean age of AntiHCV (+) population was $59 \pm 2.4$. There was a statistically non-significant difference between patients with Anti-HCV (+) and Anti-HCV (-) for age ( $p>0.05)$. Histologic types of lung cancer were $38.3 \%$ squamous cell cancer, $30.0 \%$ adenocarcinoma, $10.0 \%$ undifferentiated, and $21.7 \%$ small cell lung cancer. The histopathologic diagnosis of 3 patients who were for anti-HCV $(+)$ was lung cancer (1 squamous cell cancer, 1 adenocarcinoma, and 1 small cell lung cancer) (Table 1$)$. There was a statistically nonsignificant difference between patients with Anti-HCV (+) and Anti-HCV (-) for histologic type of lung cancer $(p>0.05$

There was no history of blood transfusion, injection drug users, surgical intervention, and hepatitis in patients with anti-HCV $(+)$. There was a statistically non-significant difference between patients with Anti-HCV (+) and Anti-HCV (-) for story of blood transfusion, injection drug users, surgical intervention, and hepatitis $(p>0.05)$ (Table 1$)$.

Table 1. Status of hepatitis $\mathbf{C}$ virus infection in lung cancer patients.

\begin{tabular}{|c|c|c|c|}
\hline & $\begin{array}{l}\text { Anti-HCV (+) } \\
(n=3)\end{array}$ & $\begin{array}{l}\text { Anti-HCV }(-) \\
(n=57)\end{array}$ & Significance \\
\hline $\begin{array}{l}\text { Gender } \\
\text { Female } \\
\text { Male }\end{array}$ & $\begin{array}{l}0 \\
3(100 \%) \\
\end{array}$ & $\begin{array}{c}2(3.5 \%) \\
55(96.5 \%)\end{array}$ & 0.741 \\
\hline History of hepatitis & 0 & $4(7.0 \%)$ & 0.646 \\
\hline History of transfusion & 0 & 0 & \\
\hline Being a injecting drug user & 0 & 0 & \\
\hline History of operation & 0 & $4(7.0 \%)$ & 0.646 \\
\hline $\begin{array}{l}\text { Histological type } \\
\text { Squamous cell } \\
\text { Adenocarcinoma } \\
\text { Small cell } \\
\text { Undifferentiated }\end{array}$ & $\begin{array}{l}1(33.3 \%) \\
1(33.3 \%) \\
1(33.3 \%) \\
0\end{array}$ & $\begin{array}{l}22(38.6 \%) \\
17(29.8 \%) \\
12(21.1 \%) \\
6(10.5 \%)\end{array}$ & 0.820 \\
\hline
\end{tabular}

\section{Discussion}

Lung cancer has frequently been cited as an example of a malignancy that is solely determined by the environment and the risks associated with cigarette smoking and certain occupations, such as mining, asbestos exposure, shipbuilding, and genetic factors , are well established (15-20). Some specific viruses has been reported at $15 \%$ role of human cancer cases (13). HCV has been shown to be associated in the etiopathogenesis 
of various malignites, including hepatocellular carcinoma, non-Hodgkin's lymphoma, oral cancer, malignant lymphoma, troid cancer $(5,6,14)$. it is not well known the association of lung cancer and HCV infection.

We found that anti-HCV antibodies were positive in 3 of 60 patients with lung cancer. Our results significantly higher than that of the normal Turkish population which was reported to vary between $0.0 \%$ and $0.6 \%$ (21). Uzun et al. reported that anti- HCV antibodies were positive in $6.7 \%$ of their lung cancer patients (22). Balci at al reported that anti- HCV antibodies were positive in $7 \%$ of their lung cancer patients (23). In our study, anti-HCV antibodies were found to be positive in $5 \%$ of our lung cancer patients.

$\mathrm{HCV}$ infection is recognized as the most common blood-borne infection in injection drug users. HCV prevalence can reach $30 \%$ to $60 \%$ within a few years of its first appearance in a population of injection drug users and achieve greater than $90 \%$ in a mature epidemic (24-28). In this study, there was no history of injection drug users in patients with anti$\mathrm{HCV}(+)$ and anti-HCV (-).

The association of blood transfusion and HCV infection is known. Dolar et al reported that anti- HCV antibodies were positive in $21 \%$ of their story of multiple transfüsion patients (29). Balci at al reported that anti- HCV antibodies were positive in $4.5 \%$ of their story of blood transfusion patiens (23). In this study, there was no history of blood transfusion in patients with anti-HCV (+) and anti-HCV (-).

Some publications, it is suggested that patients with HIV infection may be at risk for developing adenocancer of the lung $(30,31)$. But it is not well known the association of cytopatoogic type of lung cancer and HCV infection. In study of Uzun et al, among $3 \mathrm{HCV}$ associated lung cancer patients, adenocancer was detected in one, adenosquamous cancer in one and squamous cell cancer in the third patient (22). In our study, among 3 HCV associated lung cancer patients, adenocancer was detected in one, small cell cancer in one and squamous cell cancer in the two patient.

In conclusion, the development of lung cancer is a multifactorial process, including the environment factors, smoking, certain occupations, and genetic factors. HCV positivity alone may not be sufficient evidence for cause lung cancer. Therefore, There is a need studies that have large numbers of patients with HCV infection and lung cancer patients for this association.

\section{References}

1. Choo QL, Kuo G, Weiner AJ, Overby LR, Bradley DW, Houghton M. Isolation of a cDNA clone derived from a blood borne non-A, non-B viral hepatitis genome. Science 1989;244:359-362.

2. Kuo G, Choo QL, Alter HJ, Gitnick GL, Redeker AG, Purcell RH, et al. An assay for circulating antibodies to a major etiologic virus of human non-A, non-B hepatitis. Science 1989;244:362-364.

3. WHO.Hepatitis C: global prevalence. Wkly Epidemiol Rec 1997;72:341-344. 
4. Tong MJ, el-Farra NS, Reikes AR, Co RL. Clinical outcomes after transfusionassociated hepatitis C. N Engl J Med 1995;332:1463-1466.

5. Duberg AS, Nordström M, Törner A, Reichard O, Strauss R, Janzon R, Bäck E, Ekdahl K. Non-Hodgkin's lymphoma and other nonhepatic malignancies in Swedish patients with hepatitis $C$ virus infection.

6. Nagao Y, Sata M, Tanikawa K, Itoh K, Kameyama T. High prevalance of hepatitis C viruc antibodyand RNA in patients with oral cancer. J Oral Pathol. 1995; 24(8): 354-60.

7. Ferri C, Caracciolo F, Zignego AL, La Civita L, Monti, Longombardo G, et al. Hepatitic C virus infection in patients with non-Hodgkin's lymhoma. $\mathrm{Br} J$ Haematol. 1994; 88: 392-4.

8. Ueda $T$, Ohta $K$, Suzuki $N$, Yamaguchi $M$, Hirai $K$, Horiuchi $T$, et al.Idiopathic pulmonary fibrosis and high prevalance of serum antibodies to hepatitis $\mathrm{C}$ virus. Am Rev Respir Dis. 1992; 146: 266-8.

9. Talliani G, Poliandri G, Clementi $C$, et al. Chronic hepatitis $C$ and diabetes mellitus. J Hepatol. 1992; 16(suppl): 116.

10. Spiro SG, Porter JC: Lung cancer-Where are we today? Current advances in staging and nonsurgical treatment. Am J Respir Crit Care Med. 2002 Nov 1;166(9):1166-96.

11. Parkin GM, Pisani P, Ferlay J. Global cancer statistics. CA Cancer J Clin 1999; 49: 33-64.

12. Postmus PE. Epidemiology of lung cancer. In: Fishman AP, Elias JA, Fishman JA et al; eds: Fishman's pulmonary diseases and disorders. New York: McGraw Hill Companies; 1998:1707-19.

13. Ferri C, La Civita L, Zignego AL, Pasero G. Viruses and cancers: possible role of hepatitis C virus. Eur J Clin Ünvest. 1997; 27(9): 711-8.

14. Montella M, Crispo A, de Bellis G, Izzo F, Frigeri F, Ronga D, et al. HCV and cancer: a case-control study in a high-endemic area. Liver 2001;21: 335-341.

15. Beckett WS. Epidemiology and etiology of lung cancer.Clin Chest Med 1993; 14:1-15.

16. Doll R, Peto R, Wheatley K, Gray R, Sutherland I. Mortality in relation to smoking: 40 years' observations on male British doctors. BMJ 1994; 309:901-11.

17. Whitesell PL, Drage CW. Occupational lung cancer. Mayo Clin Proc 1993; 68:183-8.

18. Cullen MR, Barnett MJ, Balmes JR et al. Predictors of lung cancer among asbestos-exposed men in the \{beta\}-carotene and retinol efficacy trial. Am J Epidemiol 2005; 161(3):260-70.

19. Niklinski J, Niklinska W, Chyczewski L, Becker HD, Pluygers E. Molecular genetic abnormalities in premalignant lung lesions: biological and clinical implications. Eur J Cancer Prev 2001; 10(3):213-26.

20. Panani AD, Roussos C. Cytogenetic and molecular aspects of lung cancer. Cancer Lett 2006; 239(1):1-9.

21. Dogan L, Haznedaroglu T. Prevalence of hepatitis A,B and C inTurkey. Eur J Clin Microbiol Infect Dis. 1992; 11(7): 661-2. 
22. Uzun K, Alıcı S, Özbay B, Gencer M, Irmak H. The Incidence of Hepatitis C Virus in Patients With Lung Cancer. Turkish Respiratory Journal, December 2002; 3(3):91-3.

23. Balcı G, Kurtul N, Dereli Ş, Ozaçar R. The prevalance of hepatitis $C$ virus in patient with lung cancer. İzmir Gögus Hastanesi Dergisi, ,2010;1:15-9.

24. Shafer KP, Hahn JA, Lum PJ, et al. Prevalence and correlates of HIV infection among young injection drug users in San Francisco. J AIDS. 2002; 31: 422-431.

25. Monga HK, Rodrguez-Barradas MC, Breaux K, et al. Hepatitis C virus infectionrelated morbidity and mortality among patients with human immunodeficiency virus infection. Clin Infect Dis. 2001; 33: 240-247.

26. European Monitoring Centre for Drugs and Drug Addiction. Annual report on the state of the drugs problem in the European Union. 2003. Luxembourg: Office for Official Publications of the European Communities, 2003.

27. Falstar K, Kaldor JM, Maher L, for the collaboration of Australian Needle and Syringe Programs. Hepatitis $C$ acquisition among injection drug users: a cohort analysis of a national repeated cross-sectional survey of needle and syringe program attendees in Australia, 1995-2004. J Urban Health 2008; 8(1):106-118.

28. Kheirandish P, SeyedAlinaghi S, Jahani M, Shirzad H, Ahmadian MS, Majidi. Prevalence and Correlates of Hepatitis $C$ Infection among Male Injection Drug Users in Detention, Tehran, Iran. J Urban Health 86(6):902-8.

29. Dolar ME, Acar Y, Ateş BK. Kronik karaciğer hastalıklarında ve bazı risk gruplarında hepatit C virüs antikor prevalansı. Gastroenteroloji 1992; 3(4): 6436.

30. Karp J, Profeta G, Marantz PR, Karpel JP. Lung cancer in patients with immunodeficiency syndrome. Chest 1993; 103: 410-13.

31. Tenholder MF, Jackson HD. Bronchogenic carcinoma in patients seropositive for human immunodeficiency virus. Chest 1993; 104:1049-53. 